\title{
FAM I $3 A$ locus in COPD is independently associated with lung cancer - evidence of a molecular genetic link between COPD and lung cancer
}

\author{
The Application of Clinical Genetics \\ 21 December 2010 \\ Number of times this article has been viewed
}

\author{
Robert P Young' \\ Raewyn J Hopkins' \\ Bryan A Hay' \\ Chris F Whittington' \\ Michael J Epton ${ }^{2}$ \\ Gregory D Gamble' \\ 'Department of Medicine, Auckland \\ Hospital, Auckland, New Zealand; \\ ${ }^{2}$ Department of Medicine, \\ University of Otago, Christchurch, \\ New Zealand
}

\begin{abstract}
Recent genome-wide association studies have reported a FAM13A variant on chromosome 4q22.1 is associated with lung function and COPD. We examined this variant in a case-control study of current or former smokers with chronic obstructive pulmonary disease (COPD, $n=458)$, lung cancer $(n=454)$, or normal lung function $(n=488)$. Sex, age, and smoking history were comparable between groups. We confirmed the FAM13A variant (rs7671167) confers a protective effect on smoking-related COPD alone (C allele odds ratio $[\mathrm{OR}]=0.79, P=0.013$, and $\mathrm{CC}$ genotype $\mathrm{OR}=0.71, P=0.024)$ and those with COPD, both with and without lung cancer $(\mathrm{C}$ allele $\mathrm{OR}=0.80, P=0.008$, and $\mathrm{CC}$ genotype $\mathrm{OR}=0.70$, $P=0.007)$. The $F A M 13 A$ variant also confers a protective effect on lung cancer overall (C allele $\mathrm{OR}=0.75, P=0.002$, and $\mathrm{CC}$ genotype $\mathrm{OR}=0.64, P=0.003)$ even after excluding those with co-existing COPD (C allele $\mathrm{OR}=0.67, P=0.0007$, and $\mathrm{CC}$ genotype $\mathrm{OR}=0.58, P=0.006$ ). This was independent of age, sex, height, lung function, and smoking history. This protective effect was confined to those with nonsmall cell lung cancer ( $\mathrm{C}$ allele $\mathrm{OR}=0.72, P=0.0009$, and $\mathrm{CC}$ genotype $\mathrm{OR}=0.61, P=0.003$ ). This study suggests that genetic predisposition to COPD is shared with lung cancer through shared pathogenetic factors such as the $4 \mathrm{q} 22.1$ locus implicating the Rho-kinase pathway.
\end{abstract}

Keywords: lung cancer, chronic obstructive pulmonary disease, $F A M 13 A$, association study, polymorphism, GTPase

\section{Introduction}

Cigarette smoking is the major risk factor for chronic obstructive pulmonary disease (COPD) and lung cancer, and accounts for $85 \%$ to $90 \%$ of cases. Genetic predisposition may explain why only $\approx 10 \%$ to $20 \%$ of smokers are diagnosed with these conditions. ${ }^{1,2}$ Recent studies have shown that COPD is present in $50 \%$ to $70 \%$ of lung cancer cases when spirometry is performed, ${ }^{3-5}$ compared with a COPD prevalence of $15 \%$ to $20 \%$ among smokers randomly recruited from the community. ${ }^{3,6,7}$ The presence of COPD is associated with a 4- to 6-fold increased risk of lung cancer compared with smoking controls with normal lung function ${ }^{6}$ or community-recruited smokers. ${ }^{3}$ The heritability of COPD and lung cancer is estimated to be $40 \%$ to $77 \%$ and $15 \%$ to $25 \%$, respectively. ${ }^{8,9}$ These observations suggest that not only is COPD an important phenotype which affects many people with lung cancer (Figure 1a), but that genes conferring a propensity to COPD may also be significant for lung cancer susceptibility. ${ }^{10}$ Further supporting this claim are
Correspondence: Robert P Young School of Biological Sciences, University of Auckland, Private Bag 92019, Auckland, New Zealand

Tel +649307 4949 ext 2635I; +64272902266

$\mathrm{Fax}+6496236456$

Email roberty@adhb.govt.nz
The Application of Clinical Genetics 20 I I:4 I-10

(C) 201 I Young et al, publisher and licensee Dove Medical Press Ltd. This is an Open Access article which permits unrestricted noncommercial use, provided the original work is properly cited.
Dovepress

DOI: 10.2147 /TACG.SI 5758 
the results of recently published genome-wide association (GWA) studies of COPD, lung function (Forced Expiratory Volume in one second, $\mathrm{FEV}_{1}$ ), and lung cancer. ${ }^{11-16}$ Despite these studies investigating different disease phenotypes, they have reported associations at several overlapping loci (Table 1). This suggests that, among smokers, some loci that determine susceptibility to COPD may also be important in the susceptibility to lung cancer.

Lung cancer GWA studies have successfully identified several novel susceptibility loci, ${ }^{11-13}$ but these studies may have severely underestimated the contribution of COPD and its underlying genetic determinants of lung cancer ("COPD-related" genes, Figure 1). ${ }^{3}$ Due to the high prevalence of COPD in lung cancer, as well as its greater heritability, genetic studies in lung cancer might improve their power to identify these COPD-related genes by using a control group of smokers who have a comparable level of smoking exposure but normal lung function ("resistant" smoker, see Figure 1a). ${ }^{17,18}$ This type of control group would represent the majority of smokers ${ }^{19,20}$ and those least likely to develop either COPD or lung cancer. ${ }^{3-7}$ It has recently been demonstrated that genetic variants that confer a protective or "resistant" phenotype might be better identified using healthy smokers as controls. ${ }^{18}$ Significant differences in COPD prevalence may exist in lung cancer GWA studies between lung cancer cases and controls, ${ }^{11-13}$ (Figure 1b) which could go unrecognized as it appears spirometry was not used to examine this possibility. ${ }^{3,17,18}$ Furthermore, spirometry can be utilized to "subphenotype" smokers (with comparable smoking histories) into smokers with normal lung function,
A

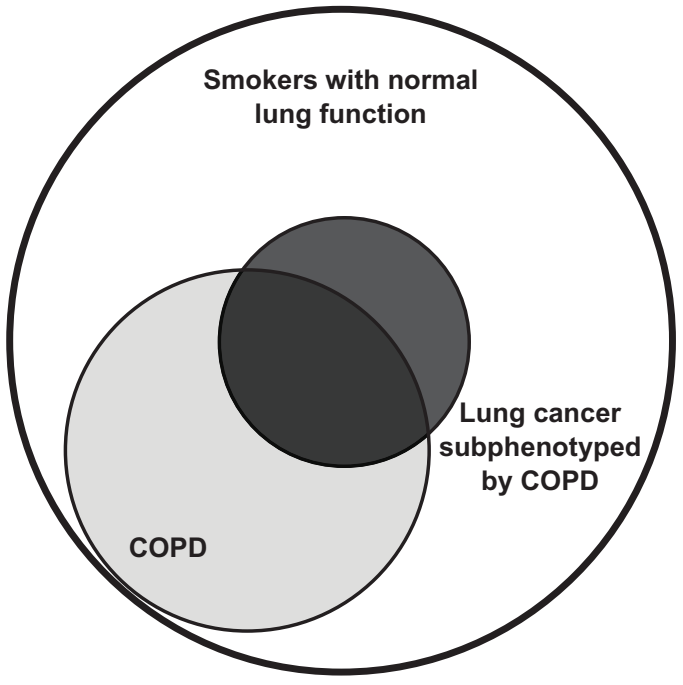

B

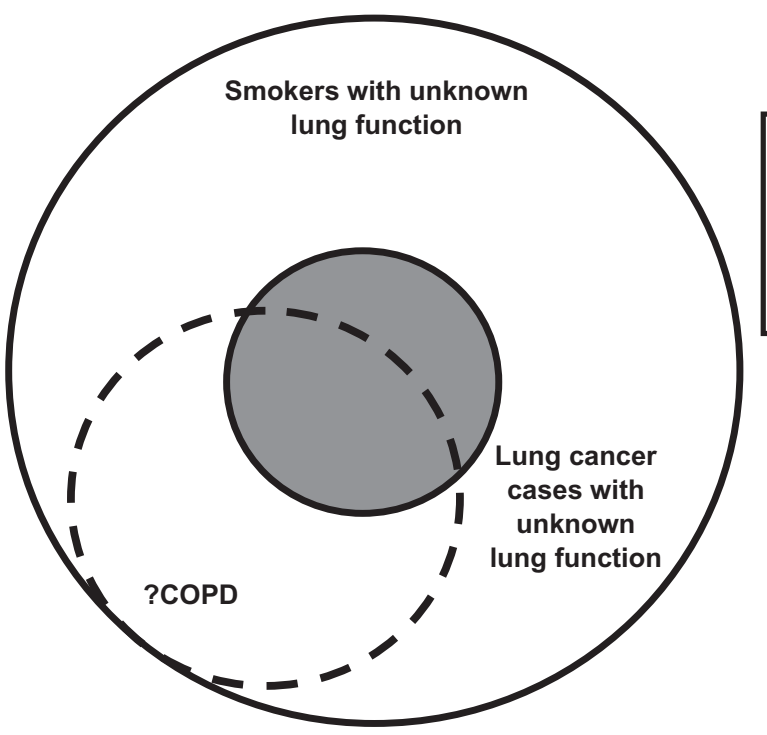

Current and former smokers with

$>15$ pack-year smoking history and spirometry performed to allow subphenotyping for COPD to reflect the overlap and in order to better establish associations.
Current and former smokers with variable smoking exposure and unknown COPD status could result in spurious associations (confounding) or no association (dilution effect).

Figure I Overlapping relationship between COPD and lung cancer in current or former smokers. A) Lung function to define COPD subphenotype and healthy smoking ("resistant") controls, ${ }^{3,17,18}$ current study. B) No lung function to define COPD subphenotype - lung cancer genome-wide association studies to date. ${ }^{11-13}$ 
Table I Chromosomal loci and candidate genes associated with COPD and lung cancer from genome-wide association studies to date $11-16$

\begin{tabular}{llll}
\hline Disease & $\begin{array}{l}\text { Candidate } \\
\text { genes }\end{array}$ & $\begin{array}{l}\text { Chromosomal } \\
\text { loci }\end{array}$ & Reference $^{\text {a }}$ \\
\hline COPD (FEV) $)$ & IL6R & Iq21 & 14 \\
& FAMI3A & $4 q 22$ & 15,23 \\
& GSTCD & $4 q 24$ & 15,16 \\
& HHIP/GYPA & $4 \mathrm{q} 31$ & $13-16$ \\
& HTR4/ADAM/9 & $5 \mathrm{q} 33$ & 15,16 \\
& BAT3/AGER & $6 \mathrm{p} 21$ & 15,16 \\
& GPR/26 & $6 \mathrm{q} 24$ & 15,16 \\
& CHRNA 3/5 & $15 \mathrm{q} 25$ & 13,14 \\
& CRP & $1 \mathrm{q} 21-23$ & 11 \\
& GYPA & $4 \mathrm{q} 31$ & 11 \\
& CRR9 (TERT) & $5 \mathrm{p} 15$ & $2,11,12$ \\
& BAT3 & $6 \mathrm{p} 21$ & $2,11,12$ \\
& CHRNA 3/5 & $15 \mathrm{q} 25$ & $2,11-13$ \\
\hline
\end{tabular}

Note: ${ }^{a}$ Available at www.genome.gov/gwastudies. Accessed 25/03/2010

Abbreviations: IL6R, interleukin-6 receptor; FAM/3A, family with sequence familiarity 13, member A; GSTCD, glutathione S-transferase; C-terminal domain containing; HHIP, hedgehog interacting protein; GYPA, glycophorin A; HTR4, 5-hydroxytryptamine receptor 4; ADAM/9, a disintegrin and metalloproteinase domain 19; BAT3, HLA-B associated transcript 3; AGER, advanced glycosylation end product-specific receptor; GPRI26, G protein-coupled receptor I26; CHRNA3/5, locus containing both cholinergic receptor, nicotinic, alpha 3 and 5 genes; CRP, C-reactive protein; CRR9, cisplatin resistance related protein; TERT, telomerase reverse transcriptase.

those with COPD, and those who have lung cancer with or without co-existing COPD. ${ }^{3}$

Using the approach described above, re-examination of the associations between genetic variants at the $15 \mathrm{q} 25$ and 4q31 loci have shown overlapping effects with COPD and lung cancer not previously reported. ${ }^{17,18}$ Specifically the chromosome 15q25 locus, which was initially associated with lung cancer in GWA studies, ${ }^{11,12}$ was also shown to be independently associated with susceptibility to COPD by Young et al. ${ }^{17}$ Subsequent GWA and candidate gene studies of COPD have confirmed this finding. ${ }^{13,21}$ In addition, Young et al have shown that the chromosome 4q31 locus, strongly associated with a reduced risk of COPD in GWA studies, ${ }^{14,15}$ also confers a reduced risk to lung cancer independent of COPD. ${ }^{18}$

Recently, two GWA studies reported variants at the 4q22 locus, within the FAM13A (family with sequence similarity 13, member A) gene, are associated with normal lung function $\left(\mathrm{FEV}_{1} / \text { forced vital capacity, } \mathrm{FVC}\right)^{15}$ and reduced risk of COPD. ${ }^{22}$ To date this gene has been poorly characterized (http://www.ncbi.nlm.nih.gov/entrez/ dispomim.cgi?id=613299, last accessed 8th October, 2010), although sequence analysis has indicated the presence of a Rho GTPase-activating protein (Rho-GAP) domain on exons $2-5$. Based on the presence of this domain, ${ }^{23}$ it is thought that $F A M 13 A$ may have tumor suppressor activity through Rho-GAP mediated inhibition of the intracellular signal transduction molecule Rho A. ${ }^{24}$ The rs 7671167 SNP, first described by Cho et al, ${ }^{22}$ is situated on intron 4 of the $F A M 13 A$ gene and in linkage disequilibrium with SNPs in the Rho-GAP domain region. The current study examines the association of the FAM13A rs7671167 SNP in similarly exposed smokers (current or former) with normal lung function, COPD, and lung cancer (where lung cancer subjects are subphenotyped for COPD) to consider the presence of shared genetic effects, such as those reported for chromosome $15 \mathrm{q} 25$ and $4 \mathrm{q} 31 .{ }^{17,18}$

\section{Materials and methods Study subjects}

All subjects recruited were of Caucasian ancestry based on their grandparents' descent (all 4 grandparents of Caucasian descent). Subjects recruited into the study were aged 40 to 80 years, with a minimum smoking history of 15 pack-years and COPD confirmed by a respiratory specialist based on prebronchodilator spirometric criteria. All subjects were recruited between 2001 and 2007. Control subjects were recruited based on the following criteria: aged 45 to 80 years and with a minimum smoking history of 15 pack-years. Control subjects were volunteers who were identified through either a community postal advertisement or while attending community-based retired military/servicemen's clubs located in the same patient catchment as those serving the lung cancer and COPD hospital clinics. Lung cancer cases were aged $>40$ years and in $95 \%$ of cases, their diagnosis was confirmed through histological or cytological specimens. Nonsmokers with lung cancer were excluded from the study and only primary lung cancer cases with the following pathological diagnosis were included: adenocarcinoma, squamous cell cancer, small cell cancer, and nonsmall cell cancer (generally large cell or bronchoalveolar subtypes). Lung function measurement (prebronchodilator) was performed within 3 months of lung cancer diagnosis, prior to surgery, and in the absence of pleural effusions or lung collapse on plain chest radiographs.

Spirometry was done in $100 \%$ of those with COPD and the smoking controls, while $93 \%$ of those with lung cancer underwent spirometry. Lung function conformed to American Thoracic Society standards for acceptability and reproducibility, with the highest value of the best three blows used for classification of COPD status. Spirometry was performed using a portable spirometer (Easy-One ${ }^{\mathrm{TM}}$; ndd Medizintechnik AG, Zurich, Switzerland). 
COPD was defined according to the Global Initiative for Chronic Obstructive Lung Disease (GOLD) spirometric criteria of II or more $\left(\mathrm{FEV}_{1} / \mathrm{FVC}<70 \%\right.$ and $\mathrm{FEV}_{1} \%$ predicted $\leq 80 \%$ ) although using prebronchodilator measurements (www.goldcopd.com). For lung cancer cases that had already undergone surgery, preoperative lung function performed by the hospital lung function laboratory was sourced from medical records. Controls with COPD based on spirometry (GOLD stage I or more) constituted $50 \%$ of the community volunteers and were excluded from further analysis. At the time of recruitment all participants gave written informed consent, and underwent blood sampling for DNA extraction, spirometry, and an investigator-administered questionnaire. The study was approved by the Multi Centre Ethics Committee (New Zealand).

\section{Study design}

The present retrospective case-control study compared smokers of the same ethnicity and comparable demographic variables (specifically age, sex, and smoking history). The healthy (resistant) controls in the current study were carefully chosen to be representative of the majority of smokers $(60 \%-80 \%)$ who have maintained normal or near-normal lung function despite decades of smoking. ${ }^{19,20}$ Accordingly, such a group allows the association with COPD to be independently assessed and COPD-related genetic associations to be identified as they ("resistant" smokers) best reflect those smokers least likely to develop lung cancer or COPD. This approach resembles a pharmacogenetic approach and minimizes phenotype misclassification of controls, thereby improving the power to detect differences between affected and unaffected smokers. ${ }^{25}$

\section{Genotyping}

Genomic DNA was extracted from whole blood samples using standard salt-based methods and purified genomic DNA was aliquoted (10 $\mathrm{ng} \cdot \mu \mathrm{L}^{-1}$ concentration) into 96-well plates. Samples were genotyped using Taqman ${ }^{\circledR}$ SNP genotyping assays (Applied Biosystems, Foster City, CA, USA) utilizing minor groove-binder probes as previously described. ${ }^{17,18}$ The present study investigated the genotype frequencies of the FAM13A SNP in the 4q22 region; rs7671167 (assay ID: C_1143656_10, Applied Biosystems) which was identified by the Cho et al GWA study. ${ }^{22}$ The rs7671167 SNP lies in intron 4 of the FAM13A gene (Figure 2a) and exhibits linkage disequilibrium (LD) with the other top SNPs identified in this region $\left(\mathrm{rs} 1903003: \mathrm{D}^{\prime}=1.0 r^{2}=0.852 ; \mathrm{rs} 2869967: \mathrm{D}^{\prime}=1.0\right.$ $r^{2}=0.64 ;$ rs6830970: $\mathrm{D}^{\prime}=0.926 r^{2}=0.365-$ Figure $2 \mathrm{~b}$ ).

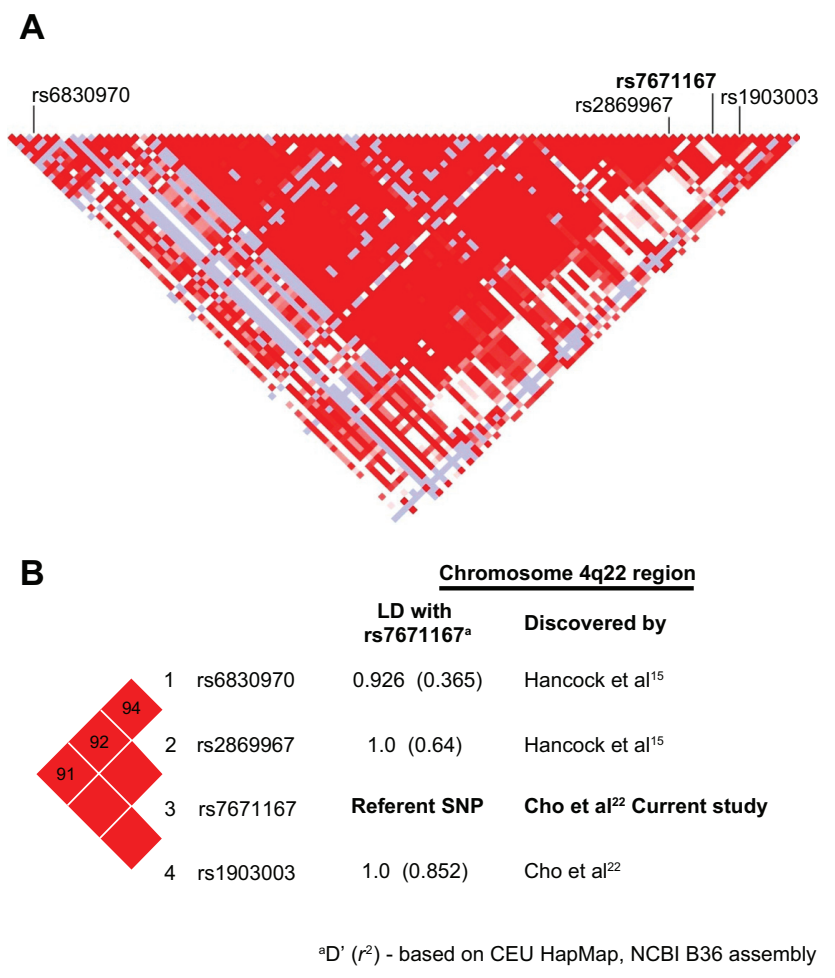

Figure 2 Linkage disequilibrium map of the chromosome $4 q 22$ region including the FAM I 3 A SNPs reported to date.

Call rates of $\geq 99 \%$ for this SNP were achieved in each group and genotyping replicated in a random sample of 150 subjects $(11 \%)$.

\section{Analysis}

Patient characteristics in the cases and controls were compared by ANOVA for continuous variables and $\chi^{2}$ test for discrete variables (Mantel-Haenszel, odds ratio [OR]). Genotype and allele frequencies for the cases and controls were examined separately for each SNP by Hardy-Weinberg Equilibrium). Population admixture across groups was performed using structure analysis on genotyping data from 40 unrelated SNPs. ${ }^{26}$ Distortions in the genotype and allele frequencies were identified between cases and controls using two-bytwo contingency tables. Both the additive- (allelic) and genotype-based genetic models were tested although the latter is preferred. ${ }^{27}$ Bonferroni correction was used for the genetic models tested above but not for the single FAM13A SNP analysis, as this study was testing for replication only.

\section{Results}

\section{Demographic variables}

Characteristics of the lung cancer cases, COPD cases and healthy control smokers are summarized in Table 2 and described in detail elsewhere..$^{3,17,18}$ The demographic variables 
Table 2 Summary of the characteristics for the lung cancer, COPD, and control smokers

\begin{tabular}{|c|c|c|c|}
\hline $\begin{array}{l}\text { Parameter } \\
\text { mean (I SD) }\end{array}$ & $\begin{array}{l}\text { Lung cancer } \\
\mathbf{N}=\mathbf{4 5 4}\end{array}$ & $\begin{array}{l}\text { COPD } \\
N=458\end{array}$ & $\begin{array}{l}\text { Control } \\
\text { smokers } \\
\mathbf{N}=\mathbf{4 8 8} \\
\end{array}$ \\
\hline$\%$ male & $53 \%$ & $59 \%$ & $60 \%$ \\
\hline Age (years) & $69(10)$ & $66(9)$ & $65(10)$ \\
\hline Height $(m)^{*}$ & $1.67(0.08)$ & $\mathrm{I} .68(0.09)$ & $1.69(0.09)$ \\
\hline \multicolumn{4}{|l|}{ Smoking history } \\
\hline Current smoking (\%) & $35 \%$ & $40 \%$ & $48 \%$ \\
\hline Age started (year) & I8 (4) & $17(3)$ & $17(3)$ \\
\hline Years smoked & $4 I(12)$ & $42(11)$ & $35(\mathrm{II})$ \\
\hline Pack-years* & $4 \mid(25)$ & $47(20)^{a}$ & $40(19)$ \\
\hline Cigarettes/day & $20(10)$ & $23(9)$ & $24(\mathrm{II})$ \\
\hline Years since quitting & II.4 (6.7) & $9.8(7.4)$ & I3.9 (8.1) \\
\hline \multicolumn{4}{|l|}{ History of other } \\
\hline \multicolumn{4}{|l|}{ exposures } \\
\hline Work dust exposure* & $63 \%$ & $59 \%$ & $47 \%$ \\
\hline Work fume exposure & $41 \%$ & $40 \%$ & $38 \%$ \\
\hline Asbestos exposure* & $23 \%$ & $22 \%$ & $16 \%$ \\
\hline \multicolumn{4}{|l|}{ Family history (FHx) } \\
\hline FHx of COPD & $33 \%$ & $37 \%$ & $28 \%$ \\
\hline FHx of lung cancer* & $19 \%$ & $11 \%$ & $9 \%$ \\
\hline \multicolumn{4}{|l|}{ Lung function } \\
\hline $\mathrm{FEV}_{1}(\mathrm{~L}) *$ & $1.86(0.48)$ & $1.25(0.48)$ & $2.86(0.68)$ \\
\hline FEV,$\%$ predicted* & $73 \%$ & $46 \%$ & $99 \%$ \\
\hline $\mathrm{FEV}_{1} / \mathrm{FVC} *$ & $64 \%(13)$ & $46 \%(8)$ & $78 \%(7)$ \\
\hline Spirometric COPD ${ }^{\mathrm{b}, *}$ & $51 \%$ & $100 \%$ & $0 \%$ \\
\hline
\end{tabular}

Notes: $* P<0.05$. ${ }^{\mathrm{a}}$ No significant difference after log transformation of pack-years

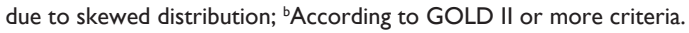

and histological subtypes of the lung cancer cases (identified in $94 \%$ of cases) are comparable with previously published data. ${ }^{28}$ The COPD cases have higher pack-year exposure than the lung cancer cases and healthy control smokers $(P<0.05)$. This reflects outliers with high smoking histories in the COPD group (skewed distribution) and no difference exists after log transformation of pack-years (data not shown). All groups are comparable for age started smoking, years smoked, years since quitting, and cigarettes/day (Table 2). Overall, we believe the 3 groups have comparable smoking exposure. The lower frequency of current smokers in the lung cancer and COPD cases, compared with the healthy smoker group ( $35 \%$ vs $40 \%$ vs $48 \%$, respectively), likely reflects the presence of symptoms from pulmonary complications of smoking (primarily breathlessness from COPD) stimulating higher quit rates.

The lung cancer cases, COPD cases, and smoking controls were also comparable for other aero-pollutant exposures. The lung cancer cases reported higher rates of a family history of lung cancer compared to the COPD cases and healthy smokers (19\% vs $11 \%$ vs $9 \%)$. Mean height was slightly lower in those with lung cancer compared to those in the control group $(P<0.05)$ but height was not different when sex adjustment was made. As expected, lung function was worse in the lung cancer and COPD cases compared to the healthy smoker controls. Testing of lung function (as described above) was achieved in $93 \%$ of lung cancer cases and allows stratification of results to test for an interactive or confounding effect of COPD.

\section{Genotype and allele frequencies}

Genotype and allele frequencies for the FAM13A rs7671167 SNP are shown in Tables 3 and 4. The genotype frequencies were consistent with those reported in the literature ${ }^{22}$ (personal communication, EK Silverman) and from the International Hapmap Project (www.hapmap.org). As SNP genotypes were confirmed with careful examination of amplification plots, replicated in 150 samples with $100 \%$ concordance and in Hardy-Weinberg equilibrium for each phenotypic group, we believe significant genotyping error can be excluded. We found no evidence for population stratification between the case and control groups using 40 unlinked SNPs from unrelated genes (mean $\chi^{2}=3.3$, $P=0.58){ }^{26}$

We found the FAM13A variant (rs7671167) confers a protective effect on the development of COPD $(\mathrm{N}=458$; $\mathrm{C}$ allele $\mathrm{OR}=0.79, P=0.013$, and $\mathrm{CC}$ genotype $\mathrm{OR}=0.71$, $P=0.024$ ) (Table 3 ), consistent with previously reported studies. ${ }^{15,22}$ We also show for the first time this FAM13A variant has a protective effect on lung cancer $(\mathrm{N}=449$; $\mathrm{C}$ allele $\mathrm{OR}=0.75, P=0.002$, and $\mathrm{CC}$ genotype $\mathrm{OR}=0.64$, $P=0.003)$, which remained significant even after excluding those with co-existing COPD (GOLD II or more) $(\mathrm{N}=207$; $\mathrm{C}$ allele $\mathrm{OR}=0.67, P=0.0007$, and $\mathrm{CC}$ genotype $\mathrm{OR}=0.58$, $P=0.006$ ) (Table 3). The association with FAM13A was also found in lung cancer where the diagnosis of COPD predated lung cancer diagnosis $(\mathrm{N}=215 ; \mathrm{C}$ allele $\mathrm{OR}=0.81$, $P=0.065$, and $\mathrm{CC}$ genotype $\mathrm{OR}=0.66, P=0.028$ ). When these cases (lung cancer with COPD) were combined with COPD cases a significant association with $F A M 13 A$ was also found $(\mathrm{N}=673 ; \mathrm{C}$ allele $\mathrm{OR}=0.80, P=0.008$, and $\mathrm{CC}$ genotype $\mathrm{OR}=0.70, P=0.007)$. We found the associations between COPD and lung cancer with FAM13A best fitted an autosomal recessive model (COPD: OR $=0.72[95 \% \mathrm{CI}$ 0.54-0.97], $P=0.037$ and Lung Cancer: $\mathrm{OR}=0.65[95 \%$ CI 0.48-0.88], $P=0.0058$ ) although this was marginal when compared with an additive model (COPD: $\mathrm{OR}=0.77$ [95\% CI 0.57-1.04], $P=0.088$ and lung cancer: $\mathrm{OR}=0.73$ [95\% CI 0.54-0.99], $P=0.049)$. Only the recessive model for lung cancer was significant after Bonferroni correction 
Table 3 Genotype and allele frequencies for the rs767II67 FAMI3A SNP in COPD and lung cancer (total and subgrouped by COPD) cohorts compared with smoking controls

\begin{tabular}{|c|c|c|c|c|c|c|c|}
\hline $\begin{array}{l}\text { Primary cohorts } \\
\text { (call rate \%) }\end{array}$ & C & $\mathbf{T}$ & $\begin{array}{l}\text { Odds ratio }^{a} \\
(95 \% \mathrm{CI})^{\mathrm{a}} \\
\text { P value }^{\mathrm{a}}\end{array}$ & CC & CT & TT & $\begin{array}{l}\text { Odds ratio } \\
(95 \% \mathrm{Cl})^{\mathrm{b}} \\
\text { P value }^{\mathrm{b}}\end{array}$ \\
\hline $\begin{array}{l}\text { Controls } N=485 \\
(99 \%)\end{array}$ & $\begin{array}{l}530 \\
(55 \%)\end{array}$ & $\begin{array}{l}440 \\
(45 \%)\end{array}$ & - & $\begin{array}{l}145 \\
(30 \%)\end{array}$ & $\begin{array}{l}240 \\
(49 \%)\end{array}$ & $\begin{array}{l}100 \\
(21 \%)\end{array}$ & - \\
\hline $\begin{array}{l}\text { COPD*N=458 } \\
(100 \%)\end{array}$ & $\begin{array}{l}448 \\
(49 \%)\end{array}$ & $\begin{array}{l}468 \\
(51 \%)\end{array}$ & $\begin{array}{l}0.79 \\
(0.66-0.96) \\
0.013\end{array}$ & $\begin{array}{l}107 \\
(23 \%)\end{array}$ & $\begin{array}{l}234 \\
(51 \%)\end{array}$ & $\begin{array}{l}117 \\
(26 \%)\end{array}$ & $\begin{array}{l}0.71 \\
(0.53-0.97) \\
0.024\end{array}$ \\
\hline $\begin{array}{l}\text { Lung cancer }(\mathrm{LC}) \mathrm{N}=449 \\
(99 \%)\end{array}$ & $\begin{array}{l}427 \\
(48 \%)\end{array}$ & $\begin{array}{l}471 \\
(52 \%)\end{array}$ & $\begin{array}{l}0.75 \\
(0.62-0.91) \\
0.002\end{array}$ & $\begin{array}{l}96 \\
(21 \%)\end{array}$ & $\begin{array}{l}235 \\
(52 \%)\end{array}$ & $\begin{array}{l}118 \\
(26 \%)\end{array}$ & $\begin{array}{l}0.64 \\
(0.47-0.87) \\
0.003\end{array}$ \\
\hline Lung cancer subgroup a & & & & & & & \\
\hline LC with COPD* $\mathrm{N}=215$ & $\begin{array}{l}212 \\
(49 \%)\end{array}$ & $\begin{array}{l}218 \\
(51 \%)\end{array}$ & $\begin{array}{l}0.81 \\
(0.64-1.02) \\
0.065\end{array}$ & $\begin{array}{l}47 \\
(22 \%)\end{array}$ & $\begin{array}{l}118 \\
(55 \%)\end{array}$ & $\begin{array}{l}50 \\
(23 \%)\end{array}$ & $\begin{array}{l}0.66 \\
(0.44-0.97) \\
0.028\end{array}$ \\
\hline LC only $N=207$ & $\begin{array}{l}185 \\
(45 \%)\end{array}$ & $\begin{array}{l}229 \\
(55 \%)\end{array}$ & $\begin{array}{l}0.67 \\
(0.53-0.85) \\
0.0007\end{array}$ & $\begin{array}{l}41 \\
(20 \%)\end{array}$ & $\begin{array}{l}103 \\
(50 \%)\end{array}$ & $\begin{array}{l}63 \\
(30 \%)\end{array}$ & $\begin{array}{l}0.58 \\
(0.38-0.87) \\
0.006\end{array}$ \\
\hline COPD subgroup analysi & & & & & & & \\
\hline $\begin{array}{l}\text { COPD* and LC with } \\
\text { COPD* } N=673\end{array}$ & $\begin{array}{l}660 \\
(49 \%)\end{array}$ & $\begin{array}{l}686 \\
(51 \%)\end{array}$ & $\begin{array}{l}0.80 \\
(0.67-0.95) \\
0.008\end{array}$ & $\begin{array}{l}154 \\
(23 \%)\end{array}$ & $\begin{array}{l}352 \\
(52 \%)\end{array}$ & $\begin{array}{l}167 \\
(25 \%)\end{array}$ & $\begin{array}{l}0.70 \\
(0.53-0.91) \\
0.007\end{array}$ \\
\hline
\end{tabular}

Notes: ${ }^{a} \mathrm{C}$ vs T compared with matched smoking controls (Mantel-Haenszel); ${ }^{\mathrm{b}} \mathrm{CC}$ vs CT/TT compared to matched smoking controls (Mantel-Haenszel); 'Spirometry available in 422/454 (93\%); COPD* = GOLD II or more criteria.

Abbreviation: $95 \% \mathrm{Cl}, 95 \%$ confidence interval.

$(P=0.01)$. Across all 3 FAM1 $3 A$ genotypes (Table 3 ) the $2 \times 3$ $\chi^{2}$ comparison for COPD and lung cancer, compared with controls, was significantly different $(P=0.041$ and $P=0.006$, respectively). The $F A M 13 A$ association was still statistically significant regardless of smoking status (ie, stratification by current and former smoker status). There was no association with the $F A M 13 A$ variant and sex, lung function, age, or height.

When the FAM13A association was examined in the lung cancer cases subdivided according to histological subtype (Table 4), we found the protective effect conferred by the FAM13A SNP was confined to those with nonsmall cell lung cancer (defined as adenocarcinoma, nonsmall cell carcinoma - unspecified, and squamous cell carcinoma) (C allele $\mathrm{OR}=0.72, P=0.0009$, and $\mathrm{CC}$ genotype $\mathrm{OR}=0.61$, $P=0.003)$ and lost in those with small cell carcinoma (C allele $\mathrm{OR}=1.02, P=0.91$, and $\mathrm{CC}$ genotype $\mathrm{OR}=0.98$, $P=0.94)$. We also found no association between this variant and lung function or smoking exposure in the lung cancer cases, the only group recruited independent of lung function criteria (Table 5). As expected, no evidence of concordance was found when genotypes from all 3 groups for the $F A M 13 A$ rs7671167 SNP (Chr 4q22) were compared with those from the HHIP rs1489759 SNP (Chr 4q31) ${ }^{18}$ which have respective positions 55 megabases apart on the long arm of chromosome 4.

\section{Discussion}

This study replicates the findings of Cho et al, ${ }^{22}$ showing the $\mathrm{C}$ allele of the FAM13A variant rs 7671167 is associated with a reduced risk of COPD (C allele $\mathrm{OR}=0.79, P=0.013$, and $\mathrm{CC}$ genotype $\mathrm{OR}=0.71, P=0.024)$. In addition, the study shows that this protective effect exists in those with COPD combined with those with lung cancer who also had pre-existing COPD (C allele OR $=0.80, P=0.008$, and $\mathrm{CC}$ genotype $\mathrm{OR}=0.70, P=0.007)$. Of greater significance, this study shows for the first time that this variant is associated with a reduced risk of lung cancer $(\mathrm{C}$ allele $\mathrm{OR}=0.75$, $P=0.002$, and $\mathrm{CC}$ genotype $\mathrm{OR}=0.64, P=0.003$ ), even after subphenotyping to exclude those with co-existing COPD (C allele OR $=0.67, P=0.0007$, and $\mathrm{CC}$ genotype $\mathrm{OR}=0.58, P=0.006$ ) (Table 3 ). The latter, together with the observation that $F A M 13 A$ genotype was not related to lung function nor pack-year exposure (Table 5), thereby excludes a confounding effect by COPD, low lung function, or smoking exposure. These findings suggest that this FAM13A variant on $4 \mathrm{q} 22$ is independently associated with a reduced risk of both COPD and lung cancer. This observation adds the 4q22 locus to those loci which also appear to be shared (or overlapping) between COPD and lung cancer on chromosome $15 \mathrm{q} 25$ (CHRNA 3/5 susceptible) and 4q31 (HHIP protective) (Table $\left.1^{11-16}\right)$. Shared genetic susceptibility may explain why there appears to be such a strong relationship between COPD 
Table 4 Genotype and allele frequencies for the rs767 I I67 FAM I 3A SNP in the lung cancer cases (subgrouped by histology) compared with smoking controls

\begin{tabular}{|c|c|c|c|c|c|c|c|}
\hline Primary cohorts & C & $\mathbf{T}$ & $\begin{array}{l}\text { Odds ratio }^{\mathrm{a}} \\
(95 \% \mathrm{CI})^{\mathrm{a}} \\
\text { P value }^{\mathrm{a}}\end{array}$ & CC & CT & TT & $\begin{array}{l}\text { Odds ratio }^{\mathrm{b}} \\
(95 \% \mathrm{Cl})^{\mathrm{b}} \\
\text { P value }^{\mathrm{b}}\end{array}$ \\
\hline Controls $\mathrm{N}=485$ & $\begin{array}{l}530 \\
(55 \%)\end{array}$ & $\begin{array}{l}440 \\
(45 \%)\end{array}$ & - & $\begin{array}{l}145 \\
(30 \%)\end{array}$ & $\begin{array}{l}240 \\
(49 \%)\end{array}$ & $\begin{array}{l}100 \\
(21 \%)\end{array}$ & - \\
\hline Lung cancer $(\mathrm{LC}) \mathrm{N}=449$ & $\begin{array}{l}427 \\
(48 \%)\end{array}$ & $\begin{array}{l}471 \\
(52 \%)\end{array}$ & $\begin{array}{l}0.75 \\
(0.62-0.91) \\
0.002\end{array}$ & $\begin{array}{l}96 \\
(21 \%)\end{array}$ & $\begin{array}{l}235 \\
(52 \%)\end{array}$ & $\begin{array}{l}118 \\
(26 \%)\end{array}$ & $\begin{array}{l}0.64 \\
(0.47-0.87) \\
0.003\end{array}$ \\
\hline \multicolumn{8}{|c|}{ Lung cancer histology subanalysis ${ }^{c}$} \\
\hline $\begin{array}{l}\text { Small cell } \\
N=78(18 \% \text { of total } L C)\end{array}$ & $\begin{array}{l}86 \\
(55 \%)\end{array}$ & $\begin{array}{l}70 \\
(45 \%)\end{array}$ & $\begin{array}{l}1.02 \\
(0.72-1.45) \\
0.91\end{array}$ & $\begin{array}{l}23 \\
(29 \%)\end{array}$ & $\begin{array}{l}40 \\
(51 \%)\end{array}$ & $\begin{array}{l}15 \\
(19 \%)\end{array}$ & $\begin{array}{l}0.98 \\
(0.56-1.70) \\
0.94\end{array}$ \\
\hline $\begin{array}{l}\text { Non small cell unspecified } \\
N=45(1 \%)\end{array}$ & $\begin{array}{l}43 \\
(48 \%)\end{array}$ & $\begin{array}{l}47 \\
(52 \%)\end{array}$ & $\begin{array}{l}0.76 \\
(0.48-1.20) \\
0.21\end{array}$ & $\begin{array}{l}9 \\
(20 \%)\end{array}$ & $\begin{array}{l}25 \\
(56 \%)\end{array}$ & $\begin{array}{l}11 \\
(24 \%)\end{array}$ & $\begin{array}{l}0.59 \\
(0.26-\mid .31) \\
0.16\end{array}$ \\
\hline $\begin{array}{l}\text { Adenocarcinoma }^{c} \\
N=19 \mid(45 \%)\end{array}$ & $\begin{array}{l}175 \\
(46 \%)\end{array}$ & $\begin{array}{l}207 \\
(54 \%)\end{array}$ & $\begin{array}{l}0.70 \\
(0.55-0.90) \\
0.003\end{array}$ & $\begin{array}{l}36 \\
(19 \%)\end{array}$ & $\begin{array}{l}103 \\
(54 \%)\end{array}$ & $\begin{array}{l}52 \\
(27 \%)\end{array}$ & $\begin{array}{l}0.54 \\
(0.35-0.84) \\
0.004\end{array}$ \\
\hline $\begin{array}{l}\text { Squamous cell } \\
N=108(26 \%)\end{array}$ & $\begin{array}{l}101 \\
(47 \%)\end{array}$ & $\begin{array}{l}115 \\
(53 \%)\end{array}$ & $\begin{array}{l}0.73 \\
(0.54-0.99) \\
0.036\end{array}$ & $\begin{array}{l}26 \\
(24 \%)\end{array}$ & $\begin{array}{l}49 \\
(45 \%)\end{array}$ & $\begin{array}{l}33 \\
(31 \%)\end{array}$ & $\begin{array}{l}0.74 \\
(0.45-1.23) \\
0.23\end{array}$ \\
\hline Nonsmall cell lung cance & binatio & ysis & & & & & \\
\hline $\begin{array}{l}\text { All nonsmall cell } N=344 \\
(82 \% \text { of total } L C, N=422)\end{array}$ & $\begin{array}{l}319 \\
(46 \%)\end{array}$ & $\begin{array}{l}369 \\
(54 \%)\end{array}$ & $\begin{array}{l}0.72 \\
(0.59-0.88) \\
0.0009\end{array}$ & $\begin{array}{l}71 \\
(23 \%)\end{array}$ & $\begin{array}{l}177 \\
(52 \%)\end{array}$ & $\begin{array}{l}96 \\
(25 \%)\end{array}$ & $\begin{array}{l}0.61 \\
(0.43-0.86) \\
0.003\end{array}$ \\
\hline
\end{tabular}

Notes: ${ }^{a} \mathrm{C}$ vs T compared with matched smoking controls (Mantel-Haenszel); ${ }^{\mathrm{b}} \mathrm{CC}$ vs CT/TT compared with matched smoking controls (Mantel-Haenszel); 'Histology available in $422 / 454$ (93\%) of lung cancer cases.

and lung cancer among smokers even after correcting for smoking exposure. ${ }^{3-7}$

Identification of the $F A M 13 A$ association with lung cancer was made possible by using smokers with normal lung function, well matched for ethnicity, age, sex, and most importantly, smoking exposure. This control group is representative of the majority of "resistant" smokers (60\%-80\%) who maintain normal or near normal lung function and therefore best represents a "low responder" phenotype. ${ }^{19,20} \mathrm{Had}$ the smoking controls for this study been recruited from hospital or community based volunteers, in the absence of spirometric screening (ie, unscreened controls), the prevalence of COPD may have been as high as $30 \%$ or more. ${ }^{29,30}$ Such an excess of COPD subjects in the unscreened controls would be expected to dilute the effect of protective variants (such as the FAM13A gene) given comparable allele and genotype frequencies in COPD and lung cancer cases compared with unscreened controls (see Figure 1 and Table 3). If this hypothesis were true, it might explain why none of the 3 lung cancer GWA studies ${ }^{11-13}$ reported an association with the $4 \mathrm{q} 22$ locus. In a similar vein, only 1 of the 3 lung cancer GWA studies identified that the 4q31 locus was implicated in lung cancer. ${ }^{11}$ This further supports the view that unscreened controls in these studies were heterogeneous and may have included many smokers with COPD (Figure 1b), thereby diluting the "protective" effect of the 4q31 locus. This would be analogous to including a high proportion of obese subjects in the controls of a genetic epidemiology study of type 2 diabetes, thereby reducing the study's power to detect relevant obesity-related genes. $^{31}$

Table 5 Relationship between FAM / 3 A genotype, smoking exposure, and lung function in the lung cancer cases

\begin{tabular}{|c|c|c|c|c|c|}
\hline \multirow[t]{2}{*}{ Gene } & \multirow[t]{2}{*}{ Genotype } & \multicolumn{3}{|c|}{ Lung function (I SD) } & \multirow[t]{2}{*}{ Pack-years (I SD) } \\
\hline & & FEV $_{1}$ (L) & FEV,$\%$ predicted & $\overline{\text { FEV }_{1} / \text { FVC }}$ & \\
\hline FAM I $3 A I$ & $\mathrm{CC}$ & $1.85(0.67)$ & $72.2 \%(22.2)$ & $65.7 \%(12.2)$ & $39.1(18.1)$ \\
\hline \multirow[t]{3}{*}{ (rs767।I67) } & CT & $\mathrm{I} .84(0.7 \mathrm{I})$ & $72.8 \%(23.6)$ & $63.4 \%(13.3)$ & $42.6(16.2)$ \\
\hline & TT & $1.90(0.68)$ & $73.1 \%(22.0)$ & $64.3 \%(12.7)$ & $40.1(13.6)$ \\
\hline & $P($ ANOVA $)$ & 0.71 & 0.97 & 0.35 & 0.65 \\
\hline
\end{tabular}


The rs7671167 SNP has no known biological function, indeed the $F A M 13 \mathrm{~A}$ gene itself is also poorly understood. $F A M 13 A$ is an interesting candidate gene because of the Rho-GAP domain it encodes ${ }^{23}$ and its associated tumor suppressor activity through inhibition of the intracellular signal transduction molecule Rho A. ${ }^{24}$ This RhoGAP activity implicates FAM13A in carcinogenesis. ${ }^{32}$ Furthermore, other proteins with Rho-GAP catalytic activity (eg, Deleted in Liver Cancer-1) function as tumor suppressors in many cancers, ${ }^{33,34}$ including nonsmall cell lung cancer. ${ }^{35-37}$ The importance of Rho-GAPs in the development of nonsmall cell lung cancer is of interest as this study found the FAM13A association was limited to this histological subtype. The relevance of this putative RhoGAP function (inhibition of Rho A) of FAM13A extends to COPD, where increased Rho A activity has been implicated in oxidative stress and impaired apoptosis underlying COPD ${ }^{38}$ For both COPD and lung cancer, differential expression of $F A M 13 A$ has been observed during pulmonary type II cell differentiation ${ }^{39}$ and in the epithelium of cystic fibrosis patients, another inflammatory based lung disease. ${ }^{40}$ Whether the rs 7671167 variant is itself functional is not known although given its location (intron 4 of the Rho-GAP domain), effects on splice variants are possible. The possibility that variable expression (or altered function) of $F A M 13 A$ plays a role in COPD and lung cancer, mediated through its putative role as an inhibitor of Rho A activity (Rho-GAP), opens the door to several possible preventive or chemotherapeutic therapies..$^{32,41-43}$ Specifically, the authors suggest that targeting FAM13A gene expression, or simulating its inhibitory function, might also have therapeutic benefit or preventive potential in COPD and lung cancer. Inhibition of Rho A and simulation of RhoGAP function has been shown to inhibit carcinogenesis ${ }^{32-34}$ and has been suggested to have therapeutic utility in the treatment of many cancers including lung cancer. ${ }^{35-37}$ In this regard, it is intriguing that Rho-GAP activity appears to inhibit the HMGCoA reductase enzyme, thereby simulating the effects of HMGCoA reductase inhibitors (statins), ${ }^{32,41-43}$ and provides a plausible explanation as to why statins may reduce the tendency to COPD and lung cancer. ${ }^{44}$ An exaggerated inflammatory/remodeling response to smoking mediated through GTPases, and the development of epithelial mesenchymal transition, are thought to link COPD and lung cancer..$^{37,38,44-46}$ Based on the results of this study, it is proposed that augmented Rho-GAP activity from variable expression (or function), conferred by FAM13A variants (or SNPs in linkage disequilibrium), may be relevant in reducing the risk of both COPD and lung cancer. Further studies will be needed to replicate these findings and ascertain the specific genetic variant/s (and functional effects) underlying the FAM13A association reported here.

In contrast to the GWA studies, ${ }^{15,22}$ this study found no correlation between the $F A M 13 A$ variant and lung function in the lung cancer cases. This may be due to several factors specific to this study including the modest size of the groups used for this analysis, the subject disease status (lung cancer cases of which $51 \%$ had co-existing COPD), the heavy smoking exposure (mean 41 packyears) or modifying effects of other smoking-responsive genes on lung function decline, eg, Chr 15q25 and Chr $4 \mathrm{q} 31$ loci. ${ }^{17,18}$ Based on our analysis and the distortions in genotype and allele frequencies, we suggest the FAM13A effect in COPD and lung cancer is most consistent with a recessive model, the former in agreement with Cho et al. ${ }^{22}$ The modest cohort size together with the case-control cross-sectional design may be considered as limitations of this study. However all subjects were well matched for all facets of smoking exposure (see Table 2) and the potential for confounding by COPD was carefully excluded. There was no interactive effect between the FAM13A variant with height, sex, and pack-years which is also consistent with Cho et al. ${ }^{22}$

In summary, there is growing evidence that lung cancer results from exposure to smoking and the net effect of genetic factors conferring beneficial or harmful pathogenic effects on the predisposition to developing lung cancer. ${ }^{47}$ Moreover, some of these genetic effects have relevance to COPD susceptibility ${ }^{10,47}$ where loci on chromosomes $15 \mathrm{q} 25$, $4 \mathrm{q} 31$, and $4 \mathrm{q} 22$ have been implicated in this overlap. ${ }^{17,18}$ The authors suggest that these 3 genetic variants represent the first examples of genetic susceptibility loci shared between COPD and lung cancer, ${ }^{17,18}$ and demonstrate the importance of using healthy smoking ("resistant") controls to identify both susceptibility (15q25) and protective (4q31,4q22) loci for lung cancer. The association with the $4 \mathrm{q} 22$ locus connecting COPD and lung cancer is of particular interest as it implicates the Rho-kinase pathway at a pathogenetic level for the first time and further supports the chemopreventive potential of existing drugs, such as statins, which inhibit Rho kinase activity. ${ }^{38,44}$ Lung cancer, rare before the 20th century, remains the single greatest cause of cancer death in the United States with approximately 440 deaths per day (28\% of all cancer deaths, 2009 figures) and in Europe with 910 deaths per day (2006 figures). Over the past 5 years, GWA 
studies and candidate gene studies have begun to elucidate the pathogenetic basis linking COPD and lung cancer as proposed by Dr Tom Petty in $2005 .{ }^{10}$ Although reduction in smoking rates must remain a public health priority, a better understanding of the genetic factors underlying susceptibility might offer new opportunities to develop novel targeted strategies for prevention or early diagnosis of lung cancer in the future..$^{44,47}$

\section{Abbreviations}

COPD, chronic obstructive pulmonary disease; FAM13A, family with sequence familiarity $13 ; \mathrm{FEV}_{1}$ forced expiratory volume in 1 second; FVC, forced vital capacity; GOLD, Global Initiative for Chronic Obstructive Lung Disease; GTPase, guanosine triphosphatase; GWA, genome-wide association; HMGCoA reductase, 3-hydroxy-3-methylglutaryl-CoA reductase; OR, odds ratio; Rho-GAP, Rho GTPase-activating protein; SNP, single nucleotide polymorphism.

\section{Acknowledgments}

This paper is dedicated to the memory of Dr Tom Petty and to the smokers with lung cancer who agreed to participate in this study. We also acknowledge the support of Dr Peter Black who died suddenly in January 2010. This study was supported by grants from the University of Auckland, Auckland Medical Research Foundation, and Health Research Council of New Zealand.

\section{Disclosure}

The authors declare no conflicts of interest.

\section{References}

1. Molfino NA. Genetics of COPD. Chest. 2004;125:1929-1940.

2. Broderick P, Wang Y, Vijayakarishnan V, et al. Deciphering the impact of common genetic variation on lung cancer risk: a genome-wide association study. Cancer Res. 2009;69:6633-6641.

3. Young RP, Hopkins RJ, Christmas T, Black PN, Metcalf P, Gamble GD. COPD prevalence is increased in lung cancer independent of age, sex and smoking history. Eur Respir J. 2009;34:380-386.

4. De Torres J, Bastarrika G, Wisnivesky JP, et al. Assessing the relationship between lung cancer risk and emphysema detected on low dose CT of the chest. Chest. 2007;132:1932-1938.

5. Wilson DO, Weissfeld JL, Balkan A, et al. Association of radiographic emphysema and airflow obstruction with lung cancer. Am J Respir Crit Care Med. 2008;178:738-744.

6. Mannino DM, Aguayo SM, Petty TL, et al. Low lung function and incident lung cancer in the United States: data from the first NHANES follow-up. Arch Int Med. 2003;163:1475-1480.

7. Tockman MS, Anthonisen NR, Wright EC, et al. Airways obstruction and the risk for lung cancer. Ann Intern Med. 1987;106:512-518.

8. Hubert H, Fabsitz R, Feinleib M, et al. Genetic and environmental influences on pulmonary function in adult twins. Am Rev Respir Dis. 1982;125:409-415.
9. Lichtenstein P, Holm NV, Verkasalo PK, et al. Environmental and heritable factors in the causation of cancer: analyses of cohorts of twins from Sweden, Denmark and Finland. N Eng J Med. 2000;343: $78-85$.

10. Petty TL. Are COPD and lung cancer two manifestations of the same disease? Chest. 2005;128:1895-1897.

11. Amos CI, Wu X, Broderick P, et al. Genome-wide association scan of tag SNPs identifies a susceptibility locus for lung cancer at $15 \mathrm{q} 25.1$. Nat Genet. 2008;40:616-622.

12. Hung RJ, McKay JD, Gaborieau V, et al. A susceptibility locus for lung cancer maps to nicotinic acetylcholine receptor subunit genes on 15q25. Nature. 2008;452:633-637.

13. Thorgeirsson TE, Geller F, Sulem P, et al. A variant associated with nicotine dependence, lung cancer and peripheral arterial disease. Nature. 2008;452:638-642.

14. Wilk JB, Chen T, Gottlieb DJ, et al. A genome-wide association study of pulmonary function measures in the Framingham Heart Study. PLoS Genet. 2009;5:e1000429.

15. Hancock DB, Eijgelsheim M, Wilk JB, et al. Meta-analyses of genome-wide association studies identify multiple loci associated with pulmonary function. Nat Genet. 2009;42:45-52.

16. Pillai SG, Ge D, Zhu G, et al. A genome-wide association study in chronic obstructive pulmonary disease (COPD): Identification of two major susceptibility loci. PLoS Genet. 2009;5:e1000421.

17. Young RP, Hopkins RJ, Hay BA, et al. Lung cancer gene associated with COPD: triple whammy or possible confounding effect? Eur Respir J. 2008;32:1158-1164.

18. Young RP, Whittington CF, Hopkins RJ, et al. Chromosome 4q31 locus in COPD also associated with lung cancer. Eur Respir J. 2010;36: $1375-1382$

19. Løkke A, Lange P, Scharling H, et al. Developing COPD: A 25 year follow up study of the general population. Thorax. 2006;61:935-939.

20. Kohansal R, Martinez-Camblor P, Agusti A, et al. The natural history of chronic airflow obstruction revisited: An analysis of the Framingham Offspring Cohort. Am J Respir Crit Care Med. 2009;180:3-10.

21. Lambrechts D, Buysschaert I, Zanen P, et al. The 15q24/25 susceptibility variant for lung cancer and chronic obstructive pulmonary disease is associated with emphysema. Am J Respir Crit Care Med. 2010;181:486-493.

22. Cho MH, Boutaoui N, Klanderman BJ, et al. Variants in FAM13A are associated with chronic obstructive pulmonary disease. Nat Genet. 2010;42:200-202.

23. Cohen M, Reichenstein M, Everts-van der Wind A, et al. Cloning and characterization of FAM13A1 - a gene near a milk protein QTL on BTA6: evidence for population-wide linkage disequilibrium in Israeli Holsteins. Genomics. 2004;84:374-383.

24. Ridley AJ. Rho family proteins: coordinating cell responses. Trends Cell Biol. 2001;11:471-477.

25. Moskvina V, Holmans P, Schmidt KM, et al. Design of casecontrols studies with unscreened controls. Ann Hum Genet. 2005;68: 566-576.

26. Pritchard J, Stephens M, Donnelly P. Inference of population structure from multi-locus genotype data. Genetics. 2000;155:945-959.

27. Thankkinstian A, Thompson JR, Minelli C, et al. Choosing between per-genotype, per-allele, and trend approaches for initial detection of gene-disease association. J App Stat. 2009;36:633-646.

28. Yang P, Allen MS, Aubry MC, et al. Clinical features of 5,628 primary lung cancer patients; experience at Mayo Clinic from 1997 to 2003. Chest. 2005;128:452-462.

29. Stav D, Raz M. Prevalence of chronic obstructive pulmonary disease among smokers aged 45 and up in Israel. Isr Med Assoc J. 2007;9: 800-802.

30. Zaas D, Wise R, Wiener C, et al. Airways obstruction is common but unsuspected in patients admitted to a general medicine service. Chest. 2004;125:106-111.

31. Frayling TM. Genome-wide association studies provide new insights into type 2 diabetes aetiology. Nat Rev Genet. 2007;8:657-662. 
32. Kandpal RP. Rho GTPase Activating proteins in cancer phenotypes. Curr Protein Pept Sci. 2006; 7:355-365.

33. Kim TY, Vigil D, Der CJ, et al. Role of DLC-1, a tumor suppressor protein with RhoGAP activity, in regulation of the cytoskeleton and cell motility. Cancer Metastasis Rev. 2009;28:77-83.

34. Yang X, Guan M, Vigil D, et al. p120Ras-GAP binds the DLC-1 Rho-GAP tumor suppressor protein and inhibits its RhoA GTPase and growth-suppressing activities. Oncogene. 2009;28: 1401-1409.

35. Yuan BZ, Jewffersen AM, Baldwin KT, et al. DLC-1 operates as a tumor suppressor gene in non-small cell lung carcinomas. Oncogene. 2004;23:1405-1411.

36. Healy KD, Hodgson L, Kim TY, et al. DLC-1 suppresses non-small cell lung cancer growth and invasion by RhoGAP-dependent and independent mechanisms. Mol Carcinog. 2007;47:326-337.

37. Asnaghi L, Vass W, Quadri R, et al. E-cadherin negatively regulates neoplastic growth in non-small cell lung cancer: role of Rho GTPases. Oncogene. 2010;29:2760-2771.

38. Richens TR, Linderman DJ, Horstmann SA, et al. Cigarette smoke impairs clearance of apoptotic cells through oxidant-dependent activation of RhoA. Am J Respir Crit Care Med. 2009;179:1011-1021.

39. Wade KC, Guttentag SH, Gonzales LW, et al. Gene induction during differentiation of human pulmonary type II cells in vitro. Am J Respir Crit Care Med. 2006;34:727-737.
40. Wright JM, Merlo CA, Reynolds JB, et al. Respiratory epithelial gene expression in patients with mild and severe cystic fibrosis lung disease. Am J Respir Crit Care Med. 2006;35:327-336.

41. Riganti C, Aldieri E, Doublier S, et al. Statins-mediated inhibition of Rho GTPases as a potential tool in anti-tumor therapy. Mini Rev Med Chem. 2008;8:609-618.

42. Walker K, Olson MF. Targeting Ras and Rho GTPases as opportunities for cancer therapeutics. Curr Opin Genet Dev. 2005;15:62-68.

43. Fritz G, Kaina B. Rho GTPases: Promising cellular targets for novel anticancer drugs. Curr Cancer Drug Targets. 2006;6:1-14.

44. Young RP, Hopkins R, Eaton TE. Pharmacological actions of statins: potential utility in COPD. Eur Respir Rev. 2009;18:222-232.

45. Dasari V, Gallup M, Lemjabbar H, et al. Epithelial-mesenchymal transition in lung cancer: Is tobacco the "smoking gun"? Am J Respir Cell Mol Biol. 2006;35:3-9.

46. Lee G, Walser TC, Dubinett SM. Chronic inflammation, chronic obstructive pulmonary disease, and lung cancer. Curr Opin Pulm Med. 2009; 15:303-307.

47. Young RP, Hopkins RJ, Hay BA, et al. A gene based risk score for lung cancer susceptibility in smokers and ex-smokers. Postgrad Med J. $2009 ; 85: 515-524$
The Application of Clinical Genetics

\section{Publish your work in this journal}

The Application of Clinical Genetics is an international, peer-reviewed open access journal that welcomes laboratory and clinical findings in the field of human genetics. Specific topics include: Population genetics; Functional genetics; Natural history of genetic disease; Management of genetic disease; Mechanisms of genetic disease; Counselling and

\section{Dovepress}

ethical issues; Animal models; Pharmacogenetics; Prenatal diagnosis; Dysmorphology. The manuscript management system is completely online and includes a very quick and fair peer-review system, which is all easy to use. Visit http://www.dovepress.com/testimonials.php to read real quotes from published authors. 